ON THE RECORD

CI am not sure that it is fair to say that it is a problem we must wrestle with.》

NASA administrator Michael Griffin discusses climate change on US radio.

\section{“Global temperature is nearing the level of dangerous climate effects.)}

NASA scientist Jim Hansen and his colleagues express a rather different view in a recent publication.

\section{SCORECARD}

\section{Meditation} Mitch Altman's Brain Machine (pictured) claims to induce a state of deep calm by synching users' brain activity to flashing LEDs and beeps.

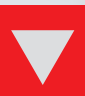

Concentration

Researchers at University College

London have developed a psychometric test to measure proneness to distraction. The test could help employers such as airlines that need staff able to... oh look, a chicken!

\section{ZOO NEWS}

\section{Cock up}

Britain's Royal Society for the Protection of Birds was ridiculed last week when its software automatically removed the word 'cock' from a forum posting about male blackbirds, replacing it with asterisks. Great tits (Parus major) are apparently still acceptable.

\section{NUMBER CRUNCH}

$15 \mathrm{~cm}$ is the average length of an erect human penis, as determined by 11,531 measurements.

$12 \%$ of men in a survey of 50,000 believed that they had small penises.

$0 \%$ of men complaining of smal penises in a similar study actually had a 'micropenis', defined as a flaccid length of less than $7 \mathrm{~cm}$.

Sources: NPR, Atmos. Chem. Phys. makezine.com, Psychol. Sci., Daily Telegraph, BJU IntI

\title{
Diplomatic talks spur hope in Libya HIV case
}

Diplomats are cautiously optimistic that a deal may be within reach, perhaps by the end of June, to save the lives of five Bulgarian nurses and a Palestinian doctor condemned to death in Libya for allegedly deliberately injecting over 400 children with HIV in 1998.

Private negotiations have recently intensified between Libya and the European Union which Bulgaria joined on 1 January - to try to find a way out of the politically charged case. Any deal would have to balance provision of humanitarian aid for longterm treatment of the infected children, and support for their families, against compromising the medical workers' defence

"The talks are going in the right direction. Let's say I'm less pessimistic than a few months ago." with implied guilt. Islamic law allows for blood money to substitute for punishment.

The medics were condemned to death on 19 December 2006. Arrested in 1999, they were first found guilty and sentenced to death in May 2004, but the Libyan Supreme Court overturned the verdict and ordered a retrial. When that retrial also found them guilty, it sparked a worldwide political and public outcry. Scientists argue that medical evidence exonerates the six, and that contaminated medical supplies and equipment caused the outbreak. This evidence was denied a hearing in court. The six have lodged an ultimate appeal to the Supreme Court, but no date has been set for this.

The case has seen many false starts, but diplomats are now cautiously optimistic that progress is being made. On 27 May, the medics were acquitted of a separate but related case of slander, for accusing police of torturing them to extract confessions.

Other political moves have been afoot. Tony Blair, Britain's outgoing prime minister, met with Libyan leader Muammar Gaddafi on a farewell trip to Africa last week. Blair's office said their discussion would include the medics' case. In public, Blair announced strengthened cooperation between the two countries - perhaps significant, as the HIV case has become an obstacle to Libya's ongoing integration into the international community.

After meeting with Blair, a representative for the infected childrens' families indicated his openness to reaching a solution. At the same time, Libya's foreign ministry issued a statement that the ongoing talks were intended "to find a solution favourable for all sides".

Nicolas Sarkozy, the new French president, made resolution of the case a foreign-policy priority in his victory speech last month. And George W. Bush, in an interview on Bulgarian

\section{Terror terms for arsonists}

Ten radical environmental activists have been sentenced over the past few weeks for a string of arsons committed in the late 1990 s and early 2000s. The group, extremists claiming to be members of the Earth Liberation Front and Animal Liberation Front, targeted scientists and sites involved in activities such as logging and the culling of wild horses. As Nature went to press, most of the sentences had been handed out, and they ranged from 3 to 13 years.

Lauren Regan, a lawyer working with the convicted

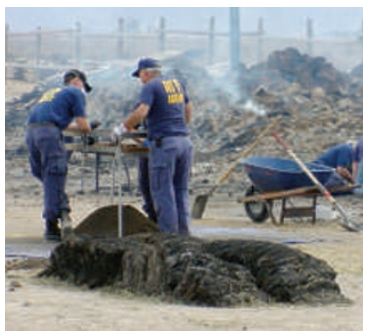

Remains of the day: arsonists destroyed many years' work.

arsonists, says the sentences are "not surprising and within the realm of reasonable", but that 'terrorism enhancements' added to many sentences will make their treatment in jail much more harsh and will label them for the rest of their lives.

The judge in the case, Ann Aiken, ruled that crimes carried out with "intent or desire to influence, affect, or retaliate against government conduct" were eligible for these enhancements. She made it clear, though, that she was ruling only on the narrow legal question of whether the crimes fit the legal criteria for the enhancement, and not on the broader, more controversial question of whether the people involved 
